\title{
Protection of Human Rights in the Criminal Procedure Legislation of the Republic Of Uzbekistan and Improved Reforms Taking Into Account Foreign Experience
}

\section{Botirjon Khayitbayevich Ruzmetov}

$\mathrm{PhD}$, Senior Lecturer, Department of Criminal law, Criminology and Fight against Corruption

Tashkent State University of Law, Tashkent, Uzbekistan

\begin{abstract}
In this article author had searched the questions devoted the protection of human rights in the criminal procedure legislation of the Republic of Uzbekistan and comparing with the legislation and worldwide experience of the foreign states. The article reveals the ongoing liberalization of the criminal law policy in the Republic of Uzbekistan, which is aimed at expanding human and fair norms, strengthening the protection of the rights, legitimate interests of a person andsociety. Against this background, the significance of investigative actions and the theory of evidence in the country's criminal procedural legislation is being revised.
\end{abstract}

The development of science and technology leads to the improvement of methods of committing crimes using computer technology, taking into account which the timely disclosure and effective investigation of socially dangerous acts requires extensive use of mathematical tools and computer technologies.In this regard, changes are taking place in the investigative practice aimed at increasing knowledge in the field of computer technologies among law enforcement officials and increasing the responsibility of the personal of the investigative and judicial authorities in the implementation of their activities. The author emphasizes that despite significant restrictions on the rights and legitimate interests of a person in the conduct of investigative actions, all of them are necessary for obtaining sufficient evidence to expose the guilt of the offender, in the manner prescribed by law.Compliance by investigators, prosecutors and judges of all criminal procedural requirements established by the legislation of the country is a key requirement for the recognition of evidence as lawful and sufficient for a fair sentence.It should be noted that the article highlights that, since 1994, the Criminal Procedure Code of Uzbekistan enshrines the right to defense by involving a lawyer in the case from the moment a person is detained on suspicion of committing a crime, as well as the principle of equality of arms in criminal proceedings. An addition to the liberalization of legislation is the fact that now the courts are freed from such unusual functions as the execution of court decisions.In addition, the article expands on the author's proposals for improving the legislation of Uzbekistan, as well as expanding the power of lawyers, especially in the conduct of investigative actions, aimed at expanding the process of liberalization of criminal law in the country and improving the situation with the protection of human rights in the investigation of criminal cases.

Keywords:Rule of law, investigative actions, evidence, lawyer, attorney, suspect, court, criminal and procedure code, foreign experience, protect the human rights,crime, legal, protection, judicial, personal search, body search, sanctions, the sanctions, law liberalization, search at the defender, criminalistics, legitimate rights.

Article Received: 10 August 2020, Revised: 25 October 2020, Accepted: 18 November 2020 


\section{INTRODUCTION}

After gaining theIndependence the Republic of Uzbekistan entered upon the path of formation of a democratic state governed by the rule of law and a marketeconomy country. To achieve these goals Sh.Mirziyayev, the President of the Republic of Uzbekistan, worked out the five guidelines for the development of the country.One of them was designated as "Supremacy of Law", which shows respectful attitude of uzbek people to the law, justice and law and order[1].

It is performed in practice that the transition period of the economic growth is characterized by positive results along with manifestations of crime in different countries as well as in our country. Crime varies not only in quantity but also in quality using more and more sophisticated techniques of commission and cover-up of the socially dangerous acts.

Nowadays, new situation arose where traditional extensive feature of investigative actions tactics improvement as techniques of deriving probative bases fall short of existing situation and there is a need for sudden change in its development by working out new tactical techniques of conducting investigative actions.

Changes of social and political realities leading to reappraisal of values in social life activity favoured the raising of personality significance in all spheres as well as in law. On the basis of these changes, the criminal law liberalization policy of the country which is aimed at extension of humane and nondiscriminatory regulations, first of all serving the interests of people and society is being realized. Stereotype and attitude to investigation of crimes are being changed subject to these realities, and the main aim of which becomes not "to punish the culprit" but "protect the rights and the legitimate interests of citizens."

In compliance with these changes it becomes necessary to revise the significance of the investigative actions and the theory of evidence at large, the essence and priorities of which should be concentrated on balanced function of accusation and justification instead of existing treatment when investigator, prosecutor, appellate court and court with supervisory authority being suspicious of any justifying data try to increase evidential basis which incriminates the accused or the prisoner at the bar.

Along with above stated factors, it should be noted that scientific and technical progress brings to sophistication of modus operandi using IT. Following the tendency of humanity transition into the informational era of full computerization, the forensic techniques and court expertise on a broad scale are switched over to the respective technologies, and there are not still means for forensic tactics of investigative actions and the theory of evidence where mathbased environments can be used actively as well as computer-aided technologies.

\section{MEHTODS}

The current study is conducted using several general scientific methods including historical, systematic, structural, comparative legal, logical, accurate sociological, scientific, comprehensive research, induction and deduction, statistical data analysis.According to the analyses of judicial investigation practice due to the poor technical and forensic provision, lack of legislative regulations of operationalinvestigative activities and legal culture level of people and the conduct of investigative actions quality as critical component of the mechanism of evidence and their effectiveness are not always characterized as on high level respectively.

"The concept of the priority directions realization of the legal and institutional framework liberalization reform", adopted by the ruling of the President of the Uzbekistan Republic Sh.Mirziyayev said that as one of the consistent policy display of the country in the sphere of the country's legal and institutional framework improvement, issued the challenge to enhance the personnel of the judicial and law-enforcement agencies' 
responsibility while undertaking their activities.

\section{RESULTS}

As a result of the study of the process of liberalization of criminal procedural and forensic aspects of the procedure for the production of investigative actions, bystudying the theoretical and practical experience of law enforcement officials, sociological questionnaires, studying the materials of criminal cases, as well asstatistical data and foreign experience, a comprehensive modern picture of the issue under study was obtained.In their study, trends and prospects for the developmentof criminal procedural and forensic theory and practice of the production of investigative actions and their function of proving at all stages of the criminal process were identified, which made it possible to come to the following conclusions and proposals:

1. Introduce into the criminal procedural legislation and the theory of criminalistics a single concept of the institution "investigative actions", which today is given a different meaning.

2. Introduction of definitions for each investigative action provided for in the Criminal Procedure: examination (Articles 135-141), examination (Articles 142-147), interrogation (Articles 96-121), confrontation (Articles 122-124), presentation for identification (Articles 125-131), verification of testimony on the spot (Articles 132-134), experiment (Articles 153-156), search (Articles 157-168), seizure (Articles 157, 159-165), arrest of postal and telegraph items (Articles 166168), wiretapping of conversations conducted from telephones and other intercom (Articles 169-171), obtaining samples for expert research (Articles 188-197), exhumation of a corpse (Article 148 -152), the appointment of examinations (Articles 172-187), the acceptance of the submitted items and documents (Articles 198-202), the introduction of objects and documents

www.psychologyandeducation.net
(Articles 203-212) - uniform definitions of concepts for consolidation in the CPC.

3. The classification of investigative actions has been improved.

4. Creation of equal conditions for the participants in criminal proceedings when submitting documents to the investigator to ensure adversariality during the preliminary investigation.

5. The expediency of removing the institution of attesting witnesses from the category of participants in criminal proceedings.

6. Based on the research results, the participants in the evidence were revised.

7. $42.6 \%$ of the respondents interviewed by the author suggested adding certain investigative actions to the Criminal Procedure Code, which allows us to conclude that the existing tools of evidence are no longer sufficient in the practice of disclosing and investigating criminal cases, and $4 \%$ of respondents suggested removing certain investigative actions from the Criminal Procedure Code from - because they are rarely used in the process of proof.

8. A detailed classification of participants in evidence in criminal proceedings is disclosed and their signs, functions and powers are substantiated. At the same time, the obligation to prove when collecting, researching and using evidence in a criminal case is proposed to be extended not only to the inquiry officer, investigator, prosecutor and court, but also to the assistant prosecutor, public prosecutor, public defender, as well as other representatives of the prosecution, including a lawyer and a representative the accused.

9. The idea is revealed and substantiated that the court cannot be assigned the procedural obligation of proof, since this contradicts the adversarial principle. On this basis, it is proposed to impose the duty of collecting evidence on the 
prosecution and defense, leaving the court only the function of assessing evidence.

10. It is proposed to include the results of operational-search activities as evidence in the criminal process, including the relevant amendments to the Criminal Procedure Code and the Law "On operational-search activities" of the Republic of Uzbekistan.

11. Relevant recommendations have been developed and substantiated for improving legislation, unregulated to date, the procedure for taking explanations from citizens and officials, including the procedure for summoning, the interview procedure, the presence of certain persons, the form and content of the documents by which all this is drawn up, as well as the procedure for requesting documents provision of legal assistance, the so-called "Legal services" to persons who are checked by law enforcement agencies.

12. Recommendations for improving the legislation were developed and substantiated, aimed at fixing in the Criminal Procedure Code, a break for rest or eating by the participants in the process after 4 hours of continuous production of the investigative action.

13. Studied the procedural order of production of all investigative actions performed at the stage of inquiry, preliminary and judicial investigation.

14. Proposals for the regulation in the legislation of Uzbekistan of investigativeactions related to the artifact of postal and telegraphic items on the Internet havebeen substantiated.

15. The detailed results of the empirical analysis of the materials of the studied criminal cases are analyzed and the frequency, as well as the procedure for the production of investigative actions in the process of trial, is shown.

16. The tactics of conducting an investigative action is considered from

www.psychologyandeducation.net the point of view of conducting a procedural action, initial actions, subsequent actions, tactics for recording the course and results of an action, as well as evaluating the results obtained.

17. The analysis of the legislation and practical experience of foreign states on theuse of the results of operationalsearch activities as evidence for the productionof investigative actions or the investigation of criminal cases in general is carriedout.

18. The foreign experience of fixing the term "investigative action" and the definition of each of the available investigative actions in the criminal procedure legislation are analyzed.

19. The foreign experience of fixing the term "investigative action" and the definition of each of the available investigative actions in the criminal procedure legislation are analyzed.

20. Taking into account the existing foreign experience, a proposal has been developed and substantiated to improve criminalistic practice and introduce amendments to the legislation of the Republic of Uzbekistan aimed at protecting victims, witnesses and other participants in criminal proceedings.

21. Studied foreign experience of procedural order and forensic tactics of conducting investigative actions and using evidence, principles of proof in the investigation of criminal cases.

22. A parallel is made of foreign experience and norms with a retrospective analysis of the legislation of the Republic of Uzbekistan in matters of "simplified proceedings", "supervision over the process of proving", the function of monitoring the preliminary investigation, the process of collecting, checking and evaluating evidence, using the results of operational-search measures in the investigation process.

23. Studied foreign legal and practical experience of the process of proving in pre-trial and trial investigation, as well 
as in jury in the investigation of criminalcases.

\section{DISCUSSION}

This task appealed to provide enhancement of the constitutional guarantees of rights and freedoms of citizens in conducting investigative actions. In this respect, the seizure and the search being the one which are investigative actions while conducted, civic rights on protection against infringement on private life and immunity of residence secured in the Article 27 of the Uzbekistan Republic Constitution and in the Article 18 of the Uzbekistan Republic code of criminal procedure have to be restricted. The real evidence of the criminal investigation can be found by means of qualitative indicated investigative actions. However, it should be remembered that departure from the norms of the criminal procedure legislation result in process of proof complications, because information or facts won't be accepted as evidence and along with it, constitutional rights and interests of the citizens will be infringed. In this connection it is appropriate to remember the words of the President of the Republic of Uzbekistan Sh.Mirziyayev, who said "the state, all branches of the government justify only if their activity follow protection and safeguarding human rights. This thesis must be recognized as fundamental, and everybody must follow it[2]."

It is expedient to revise international criminal procedure legislation for comprehensive research of execution of the seizure and conducting the search during the pretrial inquest. The analysis of juridical legislation of foreign countries' shows the existence of the definitions to the investigative actions including search and seizure. Particularly in the Article 139 of the Austrian criminal procedure legislation, the definition of the search means "investigative actions where flat or other premises are searched and where hiding and wanted person or documents and the articles relating to the criminal case might be supposedly found." In the next section of the Article body search is defined as investigative action which includes search the articles and documents relating to the case in the body and clothes of the suspected person[3].

The Switzerland legislation also contains definitions to "personal search" and "body search." According to the Article 250 of the Criminal Procedure Code (CPC) of Switzerland, the term "body search" is defined as physical and psychological search of the body. Meanwhile it is noted in the Article 249 of the Criminal Procedure Code of Switzerland that personal search contains the search in the clothes, luggage, and vehicles as well as on the body without any devices - for the articles and documents relating to the case[4].

It is noteworthy that in many countries - the vehicle search does not relate to the premises search but to the personal search as it is fixed in the Article 56 of the CPC of France.

It should be noted that functions and tasks of the search coincide in almost all countries. It is indicated in the Article 247 of the CPC of Italy that the search is conducted for retrieval and seizure of the articles which have probative value to the investigation case, and the search is conducted for seeking and arrest of the wanted individuals that is fixed in the Article 103 section 1 paragraph "b". In item 245 CCP of Switzerland it is fixed, that the search is carried out for search of subjects or the documents important for criminal case, and in item 208 is specified, that the search also is spent for capture of the searched person which presence it is necessary to provide on criminal case[5]. On the analogy of the previous countries, it is fixed in the Article 94 and the Article 102 of the CPC of Germany that the search is necessary to detect and seize any articles and documents which are significant to the investigative case and also to seek hiding individuals from investigation[6]. According to the Article 182 of the CPC of the Russian Federation, the search purposes consist in the search and seize of the articles and documents as well as in finding the wanted individuals. 
Along with general features between legislation of different countries there is essential difference in the procedure of conducting a search.

First, there is a difference in the category of individuals who are authorized to conduct a search. According to the Article 190 of the CPC of Switzerland and the search is conducted by the court, public prosecutor and police[7]. According to the Article 56 of the CPC of France, the police officer is authorized to conduct a search, and the court judge personally conducts a search by separate categories of criminal cases which are different from Switzerland practice. In accordance with the Article 109 of the CPC of Germany, the judicial police conduct a search and all procedures, but in case of arrest post and telegraph corresponds in relevance with the Article 100 of the CPC, this action is conducted only by a judge. Though for urgent reasons, police is assigned to lead apt investigative actions which without familiarization with the mail, seal and bring it to the judge, who personally examine it and defines if the mail should be joined or returned.

Secondly, there are differences relating to the authority of law enforcement bodies, which are authorized to give sanction to conduct a search. Particularly it is fixed in the Article 247 of the CPC of Italy; the Article 183 section 3 of the CPC of the Russian Federation, the Article 240 of the CPC of Switzerland that the searches are conducted by the sanctions or warrants of the court. However in the Article 18 section 2 of the CPC of France there is a reservation that the court informs the public prosecutor about the forthcoming investigative action before releasing a sanction for conducting a search[8].In the Article 256 of the CPC of Italy the court coordinates the settlement with the chief of Ministers Council of Italy while sanctioning the search relating to the state secrets, the last must provide an answer in 60 days, and in the absence of the answer, the court settles the question itself .In our opinion, the most liberal requirements are fixed in the Article 98 of the CPC of
Germany, where conducting a search with the court order, and in case of urgency by authority of the public prosecutor[9].

Protection guarantees of civil rights in foreign legislation can be foreseen in the following examples. It is indicated in the Article 244 of the CPC of Switzerland that the search may not be conducted during night time from 8 p.m. till 6 a.m., as well as on Sundays and weekends (holidays). This norm is directed to decrease inconveniences for people, though ifnecessarythe search may be conducted at indicated time.

Moreover, it is stated in the Article 56-1 of the CPC of France, that the search at the defender of the accused can be conducted by the court sanction and with mandatory presence of the head of the Bar, whose presence directed to protect the rights of the defender himself. Similar norm contains in the Article 103 of the CPC of Italy, where it is stated that the search in the office or in the house of the defender is conducted only by the judge or by the entrusted public prosecutor in cases when the defenders themselves are suspected in committing a crime or hiding the articles, documents or the wanted. The peculiarity of the "search at the defender" is that if found documents are the evidential for the protection of the defender's client and they are not part and target of the crime, they are not to be seized from the defender [10].

This foreign experience has not been applied yet in the CIS and it demonstrates necessity for criminal procedure legislation to be revised in parts relating to the search. Taking into account above stated circumstances and for ensuring protection of the defenders' (counselors') rights themselves while conducting a search against them or their premises, it is expedient to create a new Article 16 of the CPC of the Republic of Uzbekistan, stating it in the following form:

"If there are reasons for assuming that the defender (counselor) has objects or documents which are parts or target of a crime, as well as incriminating his accompliceship or for hiding the wanted, by 
ad sectam of the investigator, the interrogator and the public prosecutor, the search or the seizure is conducted by the judge himself in the dwelling, the office or in other premises of the defender (counselor).

Along with other participants stipulated by the present Code, participation is binding on the head of the Bar by territorial principle when the seizure and the search at the defender (counselor) are conducted.

The articles and documents which are evidence for the client's protection in criminal case where the defender takes part in are not subject to be seized."

Our proposing of conducting a search or seizure from the defenders by the judge personally is directed to avoid abuse by the investigators, interrogators or the attorney who are also public prosecutors, and to prevent from possible firsthand view and seizure of exculpatory evidence of the defenders client.

In our view, section 1 of the Article 140 of the CPC of Austria is deserved attention, in compliance with it, the individual who conducts a search has not a right to interrogate at the same time the individual, who is under search and must be interrogated before the search. This practice is not in compliance with the criminalistics practiced in Uzbekistan, where questioning the individual under the search is used to find the articles sought-for.

It is also fixed in the Article 141 of the CPC of Austria that in the presence of reasons, the search is conducted in the house of the judge or the law enforcement official by the officials of the same body in general terms [11]. In our view, Austrian practice complicate ascertainment of the truth on the case because the colleagues can conceal evidence or do not conduct a search, or give him/her notice about upcoming search to save prestige or for esprit de corps while conducting a search or seizure at the colleague. In our opinion, it is expedient to engage officials of other bodies in such cases.

Seizure and search in the hardware and other computer sources are ordered in the CPC of foreign countries. In accordance with the Article 97 of the CPC of Germany, computer audio, video and other files containing direct and indirect relation to the case seized with the court order are subject to be searched as well as objects and documents. In the Article 98 (b), it is noted that only data allowing establishing the truth about the case are subject to be attached to the criminal case, and other information seized during the search is subject to be returned. Seizure of the correspondence of the computer environment sources is stated in the Article 99 [12].

Analogic provision is fixed in the Article 243 of the CPC of Switzerland, according to it the objects, audio, video and other electronic documents or computer data as well as software for recording information relating to the case are subject to be seized. It is also stated in the Article 246 that hiring a specialist for finding and seizure of computer data is legal.

Using the computer data as evidence is reflected in the legislation of Kazakhstan. It is stated in the Article 236 of the CPC of Kazakhstan that operative services intercept massages transmitted through computer communication channels, and intercepted information is passed to the investigator. It is obvious from the above given examples that technical innovation is important to be regulated in the legislation to increase efficiency of crime exposure.

It is obligatory to inform competent authorities when search is conducted without an order as stated in the CPC of foreign countries so in the legislation of Uzbekistan. Particularly in the Article 240 section 2 of the CPC of Switzerland reads as follows, when search is conducted without a court order, judicial body must be informed about undertaken investigatory action, though time is not fixed in the regulation during which it is necessary to fulfil the requirement.In contrast to that in the Article 98 section 2 of the CPC of Germany, it is 
fixed 3 day time for informing the court about the conducted urgent search. In accordance with the Article 100 of the CPC of FRG analogic procedure is practiced during the seizure of correspondence.

On the basis of the given examples of foreign experience and ongoing socialeconomic reforms, the Criminal Procedure Code of the Uzbekistan Republic needs specific changes which are directed in the first place to protect civil rights and legal interests. Particularly there appear to be sufficient reasons to increase powers of the court in connection with delegation of rights to the courts to give sanctions to conduct a search and other investigatory actions infringing constitutional civil rights, as now sanctions for conducting of all investigative actions stipulated by the Article 29 section 3, the Article 36 section 2, the Article 89 section 1, the Article 148, the Article 382 section 3 paragraph 8 of the CPC of the Republic of Uzbekistan are given by the public prosecutor. Increasing powers of the attorneys especially while conducting investigative actions shall allow extending process of liberalization of the criminal law legislation in the country as well.

In addition, the expected changes can substantially improve evidential functions of the law enforcement bodies of the Republic of Uzbekistan, detect and conduct investigation more effectively as well as extend cooperation with other states in this sphere.

After the declaration of independence, Uzbekistan proceeded to formation of democratic and law-governed state. As Uzbekistan fell heir to ideologized judiciallegal system of the previous one, under the general superintendence of the President of the Republic of Uzbekistan tasks on its reformation were set, and it primarily touched upon ensuring true the autonomy and independence of judges [13].

The grounds of implementing judicial reform were laid down in the constitution of the Republic of Uzbekistan which proclaimed the principle of separation of powers. In accordance with this principle, along with legislative and executive branches of state authority judiciary branch is autonomous and independent. It became necessary to direct the court's activity to ensuring of law supremacy, social justice, and civic peace and harmony.

Bases for building of judicial power, in accordance with the national Constitution, were set out in Courts Law dated September 2, 1993 which includes major principles of judicial system that meet up-to-date world standards and rules of international law such as, equality of citizens before the law and court, presumption of innocence, adversarial character of the judicial process, right to defense and others.

Article 108 of the Constitution of the Republic of Uzbekistan for the first time allowed for establishment of Constitutional Court Proceedings Institute. Since that time the Constitutional Court of the Republic of Uzbekistan has been considering the cases with a view to constitutionality of legislative and executive acts. So, in order to implement the checks and balances system article 1 of the Law "On Constitutional Court of the Republic of Uzbekistan" included the right of Constitutional Court to question constitutionality of laws and other acts passed by the Oliy Majlis of The Republic of Uzbekistan, decrees of the President of Uzbekistan, governmental and local administration regulations, interstate treaty commitments and others [14].

Adoption of Criminal Code, Code of Criminal Procedure and Code of Administrative Responsibility in 1994 was a significant step in judicial-legal reforms. These codes reflect the standards which meet the democratic principles of lawgoverned-state and make them different from previous acts in this sphere. For instance, the Criminal code reviews the system of punishment subject to establishing of criminal responsibility by law which is adequate for the crime committed. Such types of punishment as exile and expulsion have been abolished. Criminal responsibility for crimes against peace and security, as 
well as for ecological crimes was introduced for the first time. Essential emphasis in the new Criminal Code is place on legal norms which are aimed at protecting the property and establishing responsibility for crimes in the sphere of economy, and at strengthening the responsibility for crimes provoking national enmity and intolerance, and for illegal sale of narcotics and psychotropic substances.

In accordance with Article 17 of the Code of Criminal Procedure of the Republic of Uzbekistan, the judge, prosecutor, investigator and interrogating officer must respect the honor and dignity of persons involved in the case. No one can be subjected to torture, violence, and other cruel or degrading treatment. It is prohibited to behave or render decisions which are degrading, lead to the disclosure of information on the circumstances of personal life, and create threat to health of individual, and also cause unreasonable physical or moral suffering.

Besides, under this Code, the right of defense may be exercised by engaging a counsel in the case from the moment of arrest of person suspected in execution of crime. Legal norms which stipulate the equality of parties in criminal procedure have a high priority. It is evidenced by abolition of supervisory functions of prosecutors and his participation in criminal proceedings as a prosecuting official.

At the moment the country is implementing the concept of profound reformation and liberalization of judiciallegal system as the major component in forming a law-governed state. The courts are liberated from the function of execution of judgments which is not characteristic of them [15].

Reforming of judicial-legal system accentuates on the specialization of courts. Specialization of criminal, civil, and commercial courts in Uzbekistan is consolidated on the basis of the Decree of the President of Uzbekistan of Republic dated August 14, 2000 "On perfection of judicial-legal system of the Republic of Uzbekistan" which ensured the improvement of quality of considering proceedings and protection of rights and liberties of citizens.

Adoption of new enactment of Courts Law in the month of December 2000 became an important stage in reforming of judicial-legal system. This enactment makes references to international practice in judicial reforms and experience of reforming of judicial-legal system which have been gained in the years of independence. Besides, conditions for further democratization and improvement of activity of courts have been created. For the purposes of ensuring the autonomy of courts, perfection of judicial system and improving the quality and effectiveness of effectuation of justice this Law provides for specialization of courts on the basis of existing courts of general jurisdiction and there were formed territorial courts. Besides, this Law for the first time introduced the appeal proceedings in trial which is aimed to protect the rights and legitimate interests of citizens and to increase the efficiency of legal proceedings.

Also, the cassation instance has been reformed: in case of disagreement with the judicial decision after coming into effect, citizens will be able to protect their rights in this instance personally and directly [16].

Liberalization of criminal and criminal procedure legislation holds a special position in judicial-legal reform in which human rights and interests have always been the subject issue. It should be noted that, fifty amendments have been introduced in the Criminal Code so far since its adoption. A particular consideration should be given to the Law of November 29, 2001, "On amendments to Criminal, Criminal Procedure and Administrative Responsibility Codes of the Republic of Uzbekistan in connection with liberalization of criminal punishment".

Under the Law the classification of crimes has been changed, the list of grave or felonies has been reduced, alternative types 
of punishment for committed crimes not connected with imprisonment have been introduced, and the Institute for reconciliation of parties has been formed. Furthermore, there has been established a limitation on imprisonment in case of indemnification for property damage caused by economic crime. And confiscation as an additional type of punishment has been excluded from the system of punishment.

More particular result of liberalization of criminal and criminal procedure legislation is that during 2002 2006 , the number of convicts sentenced to imprisonment has been reduced from 76000 to 34000 , that is, nearly half the number [17].

Judicial-legal reforms resulted in considerable strengthening of guarantees of judicial protection of citizens and measures on maintenance of its availability have been implemented. Expansion of the scope of judicial protection has also been promoted by adoption of Labor, Civil Procedure, Commercial Procedure Codes, Laws "On appeal to courts against actions and decisions violating the rights and freedom of citizens", "On judicial recourse of citizens", "On Arbitration Courts", "On Representative of Oliy Majlis of the Republic Uzbekistan for human rights (Ombudsman)", and a number of other regulatory legal acts.

The Decree of the President of the Republic of Uzbekistan of June 14, 2005 "On actions of further perfection of legal protection system of entrepreneurial activity" has been an important step in expansion of courts functions. In accordance with this Decree on July 1, 2005 was introduced the judicial order of application of measures of legal effect such as activity termination, confiscation of subject of infringement, application of financial sanctions.

Adoption of the Decree of the President of the Republic of Uzbekistan in 2005 "On abolition of capital punishment in the Republic of Uzbekistan" has become the next important step in liberalization of criminal legislation. This decree includes the norms of excluding the death penalty from the system of criminal punishments and its replacement with lifelong or long-term of imprisonment. Since lifelong imprisonment is a reliable legal tool which provides strict, but fair punishment for gravest crimes, inevitability of responsibility for their commission. The mechanism of automatic relief from criminal liability or from execution of a punishment due to expire of time limitation or from conditional early discharge is not applied to lifelong imprisonment.

The law also stipulates that lifelong imprisonment is established only for intentional homicide under aggravating circumstances or terrorism which caused human fatality or other grave consequences. It indicates that the criminal legislation of Uzbekistan in terms of application of lifelong imprisonment is one of the most liberal ones in the world practice. For comparison: in such countries as Germany and Poland lifelong imprisonment may be prescribed for 5 crimes, in Belgium and Russian Federation for - 6, in Denmark - 9, in Georgia - 11, Sweden - 13, Belarus - 14, Japan and Azerbaijan - 16, Kazakhstan and Korea - 17, France - 18, Netherlands - 19, Moldova - 24 .

The powers of courts in providing effective protection of rights of citizens have been considerably expanded in connection with the transfer by public prosecution bodies to courts of right to issue sanction on confinement under guard (establishing "Habeas Corpus" institution) since January 1, 2008. Establishing the institution of "Habeas Corpus" corresponds to articles 19, 25 and 44 of the Constitution of the Republic Uzbekistan, which define the rights of citizens to judicial protection. Thereupon, on July 11, 2007 there was adopted the Law on Amendment to Criminal Procedure Code, as well as the Laws "On courts" and "On Public Prosecution".

The Law of the Republic of Uzbekistan "On Amendments to some 
legislative acts regarding improvement of the order of execution of criminal punishment with fine" was adopted in 2008. It provides inevitable responsibility for committed crime, as well as the creation of procedural legal mechanism of compulsory execution of criminal punishment with fine.

According to the experience of developed countries and critical analysis of past period of work on reforming the judicial-legal system it is impossible to succeed in political and economic renewal and modernization of the country without maintenance of further increasing of the role and position of judicial bodies in the government, strengthening their powers, autonomy and independence.

At present measures on further improvement of juridical education and development of legal science, radical improvement of quality of training of personnel able to meet modern requirements, increasing of efficiency of lawmaking and enforcement matters are being developed.

Besides, at the present time in coordination with the Supreme Court and the Supreme Economic Court of Uzbekistan will be approved the program of adoption of up-to-date information-communication technologies in activity of courts. For its realization it is planned to form separate divisions on informatization within the structure of courts.

Moreover, at present there is implemented the practice of undergoing compulsory training and internship in lawyers professional advancement centers under the Ministry of Justice and Supreme Court and Supreme Economic Court for persons newly appointed (elected) as judges. All these measures are aimed at improving the skill level of judicial officers of the Republic of Uzbekistan.

At present, special emphasis is also put on further improvement of juridical education and development of legal science, radical improvement of quality of training of personnel capable to meet modern requirements, and increasing of efficiency of legislative activity and law enforcement.

In Uzbekistan system measures are being carried out on liberalization of judicial-legal system by ensuring equality of procedural rights of conviction and defendant parties, as well as their competitiveness. As it is known, after the adoption of the Law of the Republic of Uzbekistan "On advocacy" on December 27, 1996, the advocacy institute has been holding an important position in solving one of the major tasks which our society is facing - formation of democratic lawgoverned state and creation of strong civil society[16]. This is why it is impossible to imagine the government policy in accomplishing this task without participation of advocacy institute. But there is still much work to be done in terms of realization of the constitutional norm which guaranteed the rights of citizens to professional legal assistance at any stage of legal proceedings, providing of organizational autonomy of advocacy, its staffing with highly-skilled personnel, strengthening of guarantees of autonomy of lawyers, increasing the authority and prestige of lawyer's profession.

In order to increase the role of lawyers and further liberalization of judiciallegal system, on May 1, 2008 the President of Republic of Uzbekistan passed a Decree "On measures of further reforming of advocacy institute in the Republic of Uzbekistan" which defines the main directions of further reforming of advocacy institute [17].

Besides, works have been performed to form a Chamber of Lawyers of the Republic of Uzbekistan on the basis of Association of Lawyers of Uzbekistan based on obligatory membership of all lawyers of the Republic of Uzbekistan. It should be noted, that the Chamber of Lawyers of the Republic of Uzbekistan is a noncommercial organization and forms a unified system of self-management of advocacy, and operates on the basis of the principle of noninterference in the activity of lawyers which 
is carried out in accordance with the legislation. The main achievement of this Law became the possibility to guarantee the equality of procedural rights of the prosecutor and defendant in criminal procedure, expansion of the rights of suspects and the accused.

It should be noted, that the world community is taking an active part in monitoring the reforms being carried out in the Republic of Uzbekistan. For example, in July of 2012 the Supreme Court of the Republic of Uzbekistan and the UN Development Program launched a joint project "Reform of Civil Justice: effective administrative court proceeding" in realization of which took part the Research Centre under the Supreme Court, Department of execution of judgments, material and financial support of courts' activity and other organizations. The project will be implemented by the end of 2014 . It will be aimed at strengthening of civil courts by introduction of advanced world practice in judicial administration, execution of judgments, and also establishment of cooperation between civil court, judicial department and society.

The project provides work at two levels, trying to connect the top-level decision-making mechanism with courts of the first instance. The special attention is given to introduction of automated process of proceeding (electronic legal proceedings): from filing of a claim to passing of final judgment.

According to experts, in Uzbekistan the problems in justice result from essential paper-work, inconsistent decisions, as well as labor-consuming bureaucratic accountability of judges As a result, the parties seeking justice face problems with timely resolution of their disputes. In order to guarantee the legal rights and interests of citizens further reform of judicial system is necessary, as well as for effective ensuring of supremacy of law by expansion of the access to justice.

The importance of the reform of justice is conditioned by the fact that more and more people are facing problems with the protection of their rights in civil and criminal legal proceedings (more than 2 million applications in 2011). Moreover, the economic growth of the country contributes to the increase of demand for such government services. As of today in Uzbekistan one judge, on the average has to deal with about 300 cases per month. That is to say, the daily load per each judge is 34 cases. Moreover, the judges spend for paper reporting more than 3 days every month, or 36 days in a year [18].

But still the limited potential of courts on administration and consideration of such quantity of cases leads to untimely consideration of cases and influences the quality of their consideration.

As the preliminary analysis shows, for resolution of their disputes claimants and respondents visit the first instance court 6-7 times on the average. Namely due to duration of adjudication and final execution of the decision, and also other objective reasons some citizens try to solve their problems out of courts.

\section{CONCLUSION}

Based on the above, through regular judicial reform Uzbekistan will be able to provide legitimate rights and interests of its citizens and effectively support supremacy of law by expansion of access to justice.It is notable that the process of reforming the judicial-legal is systematic, stage-by-stage and continuous process.

This is evidenced by the Decree of the President of the Republic of Uzbekistan dated August 2, 2012 "On measures of radical improvement of social protection of workers of judicial system" which includes a number of measures on further reforming of judicial-legal system of the Republic for the purpose of strengthening the legal and social guarantees for independent legal proceedings and protection of social status of workers of judicial bodies.

Within the framework of implementation of this program, works are 
being performed on strengthening of autonomy and social protection of judges by approval of categories for remuneration of judges on single wage rates distribution, and also the amount of monthly increment to official salaries of the judges who have a class rank for special working conditions.

This decree is aimed at maintaining the further increasing of the position and role of judicial bodies in the government, strengthening their powers, and also autonomy and independence. The decree also provides making corresponding amendments to the current legislation regarding newly appointed judges which are required to pass compulsory training and internship in lawyers professional advancement centers under the Ministry of Justice and Supreme Court and Supreme Economic Court.

Thus, modern trends of reforming of judicial-legal system of the Republic of Uzbekistan are logically built, stage-bystage strategy of deepening of democratic reforms in the country as a whole. It is notable, that in 21 years history in our republic a number of key steps have been undertaken to improve the legislation which could freely compete with the most advanced and developed states of the world the legislation of which have more than a century history.

It is also obvious that the process of perfection of the legislation of Uzbekistan has affected all branches of authority and all spheres of public relations in order to create a high-grade base which guarantees the protection of human rights. Thus specified measures are aimed at strengthening the autonomy and social protection of judges for further increasing of position and role of judicial bodies in the government, strengthen their powers and independence which is aimed to create additional conditions of impartial realization of their powers in protection of rights and legitimate interests of the Republic of Uzbekistan.

\section{REFERENCES}

[1] Code of criminal procedure of
Austria www.strafverteidigerfriis.at/StrafprozessordnungStPO/Strafprozessordnung-StPO.pdf

[2] Code of criminal procedure of Switzerland

http://www.admin.ch/ch/f/ff/2006/13 73.pdf

[3] Code de Procededure penale. Trentieme Edition. Jurisprudence Generale dalloz 11. Rue soufflot 75240 Paris cedex 05. - 1988-1989. - Art.56. - P. 94.

[4] Code of criminal procedure of Italy www.studioaterno.it/documenti/Codi ce\%20Procedura\%20Penale.pdf

[5] Code of criminal procedure of Germany www.gesetze-iminternet.de/bundesrecht/stpo/gesamt. pdf

[6] Code de Procededure penale. Trentieme Edition. Jurisprudence Generale dalloz 11. Rue soufflot 75240 Paris cedex 05. - 1988-1989. - Art.56. - P. 92-93.

[7] Code of criminal procedure of the Republic of Kazakhstan http://base.zakon.kz/doc/lawyer/nphlawyer.exe?uid=;\&uid=4B2491A76402-411B-9C9799B8B3275022\&language $=$ rus \&doc _id=1008442\&language $=$ rus\&forpri nt

[8] Theoretical and practical commentary to the Code of criminal procedure of Russian Federation / Under general version by V.M. Lebedev, V.P. Bojyeva - 2nd edition. - M.: Spark, 2004. - P. 372373.

[9] Register of the Supreme Council of the Republic of Uzbekistan. No. 10. 1993. - Page 367.

[10] Register Oliy Majlis of the Republic of Uzbekistan. No. 9. 1995. - Page 178. 
[11] Collection of the legislation of the Republic of Uzbekistan. No. 11. 2000. - Page 155.

[12] Abdumajidov G.A., Polvonzoda A. Supremacy of court in Uzbekistan: prosperity of the age. Tutorial. - T. : Adolat, 2002. - Page 23.

[13] Rustambayev M.H. Establishment of judicial supervise to pre-judicial process //Some questions of application of imprisonment: international standards and foreign experience. Materials of the international scientific and practical conference. April 27, 2007. - T.: TSLI, 2007. Page 7-13.

[14] Norboyev A. Legal grounds of abolition of the death penalty// Judicial and legal reform: current condition and the prospects of improvement. Materials of scientific and practical conference, on May 17, 2007. - T.: TSLI, 2007. - Page 9294.

[15] Inogomjonova Z.F. Judicial control in criminal trial. Tutorial. T.: TSLI, 2009. - Page16.

[16] Bazarov A. Procrastination of justice - is denial of justice http://www.undp.uz/en/download/ind ex.php?type $=$ publication $\&$ id $=309 \& p$ arent $=5863 \&$ doc $=113536$

[17] Nigmatov K.I. Respect of court - the main sign of judicial system independence // Huquq va burch - 2009. - No. 5 - Page 13-14. 